\title{
FARM TAXATION POLICY IN UKRAINE AND POLAND
}

\author{
Oleg Dannikov, $\mathrm{PhD}^{1 *}$, Associate Professor; Inna Ivasko, $\mathrm{MSc}^{2}$
}

State Institute of Economics and Forecasting, National Academy of Sciences of Ukraine

${ }^{*}$ https://orcid.org/0000-0002-2736-0992

\begin{abstract}
The article discusses the shortcomings of tax policy in the agrarian sector of the economy of Ukraine, which has created non-competitive conditions for small farms. Large agricultural enterprises in Ukraine use the existing special tax regime as an optimization of tax liabilities. This has led to such negative economic, social and environmental consequences as the development of landlands, the deterioration of agricultural landscapes, the increase in export-oriented production, the growth of unemployment in the village and the migration of the rural population. While small farms, without state support, provide the population with basic foodstuffs. The purpose of the article is evidence of the use of a special tax regime only for small farms, based on an analysis of the special tax treatment regime in Polish agriculture and an analysis of the differential rent methodology laid down in the basis of a special tax regime, as well as the development of practical recommendations for Ukraine.
\end{abstract}

Key words: tax regulation, special tax regimes, land rent, agrarian sector, agriculture, foreign experience JEL codes: H3, Q01

\section{INTRODUCTION}

The role of small farms is reinforced by the FAO doctrine developed at the 1996 European conference. According to this doctrine, the economic function of agriculture is complemented by such important non-market functions as: social (food security, employment, solution of demographic problems) and ecological (conservation of soil fertility, the formation of rational agricultural landscapes, protection of water resources) European Council (1996). As a result of the 2001 European conference in the global agrarian economy, it acquired the name "multifunctional agriculture" European Council (2001). The desire to maximize profits through the concentration and intensity of production, lead the loss of agriculture, not only environmental, but social functions.

Therefore, government regulation of such instruments as special tax regimes should be conducive to the development of small forms of management, providing the concept of multifunctional agriculture.

In Ukraine, due to the lack of a doctrine of development of multifunctional agriculture and the corresponding state regulatory policy, classic capitalist enterprises are rapidly developing. At the end of the 1990 s, the institutional structure of the agrarian sector consisted mainly of concentrated private enterprises, formed through the reorganization of collective agricultural enterprises. The peasants, who received land plots of approximately 2 ha, leased them or cultivated

\footnotetext{
${ }^{1}$ Corresponding author: P. Mirny 26, 01-011 Kiev, Ukraine, mr.dannikoff@yandex.com

${ }^{2}$ Corresponding author: P. Mirny 26, 01-011 Kiev, Ukraine, inna.ivasko@gmail.com
} 
them on their own. The production and profitability of the corporate sector during the independence of Ukraine was falling at an enormous pace, and by 1998 93\% of agricultural enterprises were already unprofitable (Ivasko, 2010). Private farms, on the contrary, showed an increase in production. The current economic situation was favourable for the introduction of a special tax regime in order to regulate the organizational structure in favour of unbundling overly large corporations into separate independent business entities and forming a class of family farmers. But in the agrarian sector of Ukraine, a special tax regime was applied specifically to support agricultural producers. In transition economies, a weak institutional environment and "soft" fiscal constraints reinforce an enterprise's incentives for vertical integration, as a mechanism for adapting to institutional inefficiencies (Dannikov, 2015). The effect of such a special regime for 20 years distorted the structure of the industry and caused the formation of latifundia in the agrarian sector, which, due to the scale of production, displaced small farms from the market, monopolizing it.

In the countries of the European community, in particular, in Poland, a special tax regime is aimed at supporting, first of all, small producers. Therefore, it became necessary to study foreign experience in applying a special tax regime in the agricultural sector and to carry out a comparative analysis of the application of these regimes in agriculture of Ukraine and Poland, in view of the similarity of the methodology for calculating the tax base.

\section{THEORETICAL BACKGROUND}

The tax policy in the agricultural sector has its own characteristics, due to the specifics of this industry, its dependence on weather and climatic conditions, inelastic demand for agricultural products and a number of other factors, therefore, special (preferential, simplified) tax regimes (Shubravskaya, Moldavan and Paskhaver, 2012).

Government policies on agricultural taxation affect the competitiveness of farms and other operators in the agricultural sector (Wasilewski and Ganc, 2012). In addition, it affects the scale, structure, organization and direction of agricultural produc- tion, and also affects the use of productive resources (Dziemianowicz, 2006; Forfa, 2011).

In Ukraine, the peculiarities of the special tax regime led to the deformation of the organizational structure of the agrarian sector in favour of large agrarian enterprises. Vertically integrated structures in the agar sector use a special tax regime that replaces profitable and land taxation as a legal form of tax evasion (Dema, 2014).

Along with the increase in the competitiveness of the agro-industrial production, the activities of agricultural holdings lead to an increase in social tensions in the village, a lack of payments to local budgets and, in general, a negative impact on the social development of rural areas (Moldavan, 2016).

The specificity of the functioning of agriculture in Ukraine at the present stage of its development lies in a significant proportion of households (small farms) in the volume of agricultural production, most of which still do not have the status of a business entity (Tulush and Hryshchenko, 2018).

Reforming the tax policy in the agar sector of Ukraine, one should take into account the specifics of taxation of farmers in EU countries, which is to simplify tax relations with small farmers and general taxation principles for large farmers and corporations.

Therefore, the development of proposals for reforming the tax policy in the agrarian sector of the Ukrainian economy, based on an analysis of the agricultural taxation policy of Poland, is of great importance.

\section{MATERIALS AND METHOD}

The purpose of the article is evidence of the use of a special tax regime only for small farms, based on an analysis of the special tax treatment regime in Polish agriculture and an analysis of the differential rent methodology laid down in the basis of a special tax regime, as well as the development of practical recommendations for Ukraine.

The methods of analysis and synthesis are used in the study of individual composite objects and the generalization of the results obtained, as well as comparative and economic-statistical methods in the process of analysing special tax regimes in the agar 
sector of Poland and Ukraine. Methodological principles and methods of a systematic approach are taken as a basis for research. They most fully take into account all aspects of the formation of tax policy for the development of small business in the agricultural sector on the basis of rental relations, taking into account the concept of the development of multifunctional agriculture.

\section{RESEARCH RESULTS AND DISCUSSION}

The organizational structure of agriculture in Poland is, by definition, $99 \%$ represented by family farms. These farms have small plots, $56 \%$ of which range from 1 to 5 ha, and the average farm size is 9.5 ha (Statistics Poland, 2011).

Family farms include:

- crop farms with an area of more than 1 ha of agricultural land,

- other farms with an agricultural land area of less than $1 \mathrm{ha}$, including without agricultural land (the so-called special branches of agricultural production). These include the cultivation of vegetables, fruits and berries in greenhouses, livestock and poultry farms (Agricultural Tax Act of 15 November 1984). The regulation of the category "family farm" in Poland was introduced in 2003. According to the Act, a farm is considered family if it meets two criteria: (1) the area of a family farm is limited to 300 ha; (2) managed by an individual farmer. These standards are introduced to limit the excessive concentration of productive capital.

Agrarian policy of Ukraine determined the creation of a class of family farms nominally for the last decades as a priority. This is confirmed by the concept of the State target program for the development of the agrarian sector of the economy for the period up to 2021, adopted by the Cabinet of Ministers of Ukraine (Resolution of 20 December 2019 No 1437-r). However, during this time, the prerequisites for the formation of a class of effective owners and the growth of incomes of peasants on the ruins of the reorganization of the collective form of business (collective farmsstate farms) were not prepared, tax measures to support small producers were not created.

Only in 2018, it was decided to amend the Farm Act of 19 June 2003, which provides households with the status of a family farm. According to this Act, these include:

- individuals - entrepreneurs;

- activity: production of exclusively agricultural products, their processing and delivery;

- do not use the work of hired persons;

- only family members of this person can be members of a family farm;

- the area of agricultural land owned and/or used, the lands of the water fund used by members of the family farm may be not less than 2 ha but not more than 20 ha.

It should be noted that the institutional structure of the agricultural sector of Ukraine is heterogeneous. These include partnerships and cooperatives (18.4\%), individual enterprises, including farms - legal entities (78.4\%), state-owned enterprises $(0.6 \%)$, and other forms of business (3.6\%).

Statistics of Ukraine keeps records of farms only legal entities. The share of such farms in Ukraine among agricultural enterprises is $70 \%$. The distribution of agricultural land between them is uneven. Thus, the largest number of farms (33.3\%) has from 20 to 50 ha of farmland in use and covers only $9.6 \%$ of the total land area, and $0.2 \%$ of farms that manage more than 4,000 ha each cover $7.7 \%$ of the total area of agricultural land, the average size of the Ukrainian farm is 106 ha. Less than $2 \%$ of agricultural enterprises of other legal forms cover $30 \%$ of the total area of agricultural land, the average area of which is more than $9,000 \mathrm{ha}^{3}$.

In Ukraine, according to unofficial statistics, at the end of 2011 there were 80 agro-industrial trading companies, and 93 in 2017. The land bank of these structures grew by $6.3 \%$ over this period and amounted to about 5.95 million ha (Polyvka, 2018).

A comparative analysis of the organizational structure of the agrarian sector of Ukraine and Poland

\footnotetext{
${ }^{3}$ Official site of the State Statistics Committee of Ukraine (in Ukrainian Gosudarstvennogo komiteta statistiki Ukrainy). Retrieved from: http: www.ukrstat.gov.ua [Access 15.04.2019].
} 
according to the size of the land shows that a large group of landowner enterprises has been formed in the Ukrainian agricultural sector, therefore most of the small farms are non-competitive, both in production costs and production volumes (Dannikov and Ivasko, 2019). Accordingly, during periods of sharp collapse in demand in the markets and falling prices, such agricultural producers are isolated from the international market.

In our opinion, this does not correspond to the European business model, which can be demonstrated by the example of Poland, in which the number of farms with an area of more than 100 ha is only $0.85 \%$ (Pylypchuk and Ivasko, 2013). We believe that an imperfect tax system of Ukraine plays a significant role in this imbalance and distortion of the competitive environment in the agricultural business.

We will conduct a detailed analysis of the special tax regime for the Polish agricultural sector. Family farms in Poland enjoy a special tax regime in the form of agricultural tax (Agricultural Tax Act of 15 November 1984), which replaces the income tax. This tax is based on the cadastral valuation of land fertility according to the type, quality and location of the land plot. From a methodological point of view, the agricultural tax of Poland is a tax on land rent, that is, on the average yield from the land.

In Poland, depending on the natural qualities of the soils, which determine the yield of agricultural crops, the land is divided into 10 main classes. Depending on the economic and production conditions in Poland, there are four tax districts with different coefficients.

The subjects of taxation are individuals and legal entities that are engaged in agricultural activities. The tax base is the number of hectares of land multiplied by the coefficient calculated in accordance with the classification of agricultural lands, including those allocated for agricultural buildings.

The tax rate is equal to the cash equivalent of the cost of $2.5 \mathrm{~kg}$ of rye, which is calculated based on the average purchase price of rye for the 3 quarters preceding the current financial year. It is assumed that the market value of rye correlates with the profitability of the farmer. As the analysis of the agricultural tax component of Poland shows, the average cost of
1 centner of rye for taxation purposes in 2015-2017 decreased by $22 \%$ compared to 2014 and in 2018 it rushed to growth.

This preferential tax treatment applies only to agricultural activities defined by law. Farmers who engage in activities in the field of special branches of agricultural production in excess of established standards pay income tax. In Poland, income taxation is progressive, but profits from special sectors of agricultural production, regardless of size, are subject to a flat rate of $18 \%$.

A legal entity that engages in mixed activities is exempt from paying income tax if, for the previous fiscal year, the amount of income from agricultural activities was at least $60 \%$ of the income from all types of activities.

In Ukraine, a special tax regime, as in Poland, is based on cadastral valuation of land. The basis of this regime is the normative monetary value of one hectare of agricultural land. The standard monetary valuation of 1 ha of agricultural land is a complex aggregate indicator that expresses the average income of the land - the differential rent.

The tax amount is calculated by multiplying the standard monetary value by the rate and area of agricultural land. Rates depending on the territorial conditions for arable land is $0.57 \%$ and $0.95 \%$, for perennial plantations $-0.19 \%$ and $0.57 \%$, for production on protected ground $-6.33 \%$ (Tax Code of Ukraine).

Since the beginning of its existence, the main essence of the special tax regime was to reduce the tax burden and simplify the payment of 12 taxes and fees, including income tax, land tax, deductions to the Pension Fund and the Social Insurance Fund. Since 2011, their number has decreased to 4 , including income tax and land tax.

During 2008-2018, it could only be used by legal entities, regardless of their legal form, whose share of agricultural production in the previous tax (reporting) year is equal to or exceeds $75 \%$. Since 2018 , not only legal entities, but also individuals can take advantage of a special tax regime.

Analysis of the dynamics of changes in the normative monetary value of land in Ukraine relative to 2014 shows its rapid growth of $+50 \%$ over the course 
of 2016-2017 through the use of a cumulative indexation rate. By 2019 in Ukraine, tax rates for farmers increased more than 5 times. Thus, the fee for 1 ha of farmland has increased to 20 USD (at the rate of National Bank of Ukraine at 1 March 2019), which is 7 times more than in 2014.

In 2012, enterprises paid 1-1.3 USD per ha of agricultural land (at the NBU rate in 2012), while in Poland the agricultural tax for 1 ha of land was about 60 USD (at the rate of pulp and paper industry in 2012). A paradoxical fact was that the Ukrainian personal peasant farms could not apply this special tax regime and paid land tax, the rates of which were several times higher.

Special tax regime in the agricultural sector of Ukraine is based on the differential land rent type I. Differential land rent type I occurs due to differences in fertility and the location of the land and agricultural activities by the extensive method. This method of cultivation of land is characteristic only for small forms of management.

Differential land rent type II arises in connection with additional capital investments in land plots such as: fertilization, improvement of agricultural technology, and reclamation work. They create "artificial" or economic fertility and increase productivity. When a farmer does business in his own land, differential rent type II remains entirely in his ownership. If the owner of the land rents it, then he receives only part of the differential rent II in the form of rent. Scientists argue that a differential land rent type III arises on the scale of a vertically integrated structure (Borodina et al., 2012).

In all cases, the source of differential rent is the excess profit received by the tenant or the owner of the land. From a methodological point of view, excess profits are the basis for calculating the income tax. And it proves the imperfection of the special tax regime in the agar sector of Ukraine, which is replaced by income tax for large agricultural enterprises.

Thus, in the agrarian sector of Ukraine, a monopoly of agricultural land is developed, where, as an object of management, it is in the monopoly use of capitalist entrepreneurs who will not allow capital investments by other such entrepreneurs on it and thus receive surplus surplus value over average profit.

\section{CONCLUSIONS}

As the analysis showed, the institutional structure of agriculture in Poland is homogeneous, the majority of which are non-food farms. This argues that the preferential tax regime based on rental income applies only to small family farms. This mode simplifies tax calculations based on the average yield of agricultural land and allows you to save on additional costs.

Analysis of the methodology for the formation of differential rent of the first and second types helped to identify the shortcomings of the methodology of the current simplified tax regime in Ukraine. This mode allows large agricultural enterprises to earn excess profits by assigning a differential rent of type II and type III, which is the basis for the payment of income tax.

Thus, our study proves that the application of a special tax regime with a simplified nature to high-yield farmers, as well as to vertically integrated companies, is unreasonable.

Therefore, in order to regulate the taxation policy of farms in Ukraine, it is necessary to establish restrictions in the application of a special tax regime, which will exclude the possibility to use it by large agrarian enterprises in order to reduce their tax liabilities and increase non-taxable excess profits.

According to Poland's experience, it is also necessary to exclude farms conducting special activity in agricultural production from preferential taxation in Ukraine, which do not depend on climatic conditions, seasonality and have a short period of capital turnover. For this, it is necessary to legally define the norms of non-production in such industries.

\section{REFERENCES}

1. Borodina, O., Heyetz, V., Gutorov, A. et al. (2012). Ukrainskaya model' agrarnogo razvitiya i eyo socioekonomicheskaya pereorientaciya: nauchn. doklad NAN Ukrainy, Institut ekonomiki i prognozirovaniya [Ukrainian model of agrarian development and its socioeconomic reorientation: scientific. Report of the National Academy of Sciences of Ukraine, Institute of Economics and Forecasting]. Natsional'naya akademiya nauk Ukrainy, Kyiv. 
2. Dannikov, O. (2015). Argumenty v pol'zu "zhestkoj" vertikal'noj integracii [Arguments in favor of "rigid" vertical integration]. Strategy for the economic development of Ukraine: a collection of scientific papers, 36, pp. 72-82.

3. Dannikov, O., Ivasko, I. (2018). Vliyanie nalogovogo regulirovaniya na strukturu agrarnogo sektora Ukrainy [Influence of tax regulation on the structure of Ukraine agrarian sector]. Regional'nyye agrosistemy: ekonomika i sotsiologiya, 3. Retrieved from: http://www.iagpran.ru/journal.php?tid $=673$

4. Dannikov, O., Ivasko, I. (2019). Vliyanie nalogovogo regulirovaniya na institucional'nuyu arhitektoniku i dinamiku ekonomicheskih preobrazovanij $\mathrm{v}$ agrarnoj sfere ekonomiki [The impact of tax regulation on institutional architectonics and the dynamics of economic transformations in the agrarian sphere of the economy]. Regional'nyye agrosistemy: ekonomika i sotsiologiya, 1. Retrieved from: http://www.iagpran.ru/journal. php?tid=733

5. Dema, D. (2014). Neobkhidnist zmin v opodatkuvanni ahrokholdynhiv [The need for changes in the taxation of agricultural holdings]. Scientific club SOPHUS. Retrieved from: http://sophus.at.ua/publ/2014_12_16_ lutsk/sekcija_7_2014_12_16/neobkhidnist_zmin_v_ opodatkuvanni_agrokholdingiv/80-1-0-1205

6. Dziemianowicz, R. (2006). Podatki i ich wpływ na konkurencyjność gospodarstw rolnych. Agrobiznes 2006 - konkurencja w agrobiznesie - jej uwarunkowania i następstwa [Taxes and their impact on competetiveness of farm businesses. Agribusiness 2006: the conditions and consequences of agribusiness competition]. Zeszyty Naukowe Uniwersytetu Ekonomicznego we Wrocławiu, 1118, pp. 216-222.

7. European Council (1996). Conclusions de la Présidence. Dublin 13-14.12.1996. Retrieved from: https:// www.consilium.europa.eu/media/21143/dublin-conseil-europeen.pdf [Accessed 17.04.19].

8. European Council (2001). Conclusions de la Présidence. Göteborg 15-16.06.2001. Retrieved from: https://www. consilium.europa.eu/media/20979/00200-r1f1.pdf [Accessed 17.04.19].

9. Forfa, M. (2011). Obciążenie fiskalne gospodarstw rolniczych w zależności od wielkości ekonomicznej oraz typu rolniczego [Farm taxation in function of economic size and agricultural type]. Zeszyty Naukowe SGGW. Ekonomika i Organizacja Gospodarki Żywnościowej, 92, pp. 89-101.

10. Główny Urząd Statystyczny [Statistics Poland] (2011). Wyniki wstępne Powszechnego Spisu rolnego 2010. In- formacja sygnalna, Warszawa 28.01.2011 [Preliminary results of the 2010 Agricultural Census. Signal news, Warsaw 28.01.2011]. Retrieved from: http://stat.gov.pl/ cps/rde/xbcr/gus/nsp_psr_2010_wyn_wstepne_konf 280111.pdf [Accessed 12.04.19].

11. Ivasko, I. (2010). Formirovanie sistemy nalogooblozheniya sel'skohozyajstvennyh predpriyatij Ukrainy [Formation of a taxation system for agricultural enterprises of Ukraine]. Bulletin of the Cherkasy Bohdan Khmelnytsky National University. Economic Sciences, 4, pp. 136-141.

12. Ivasko, I. (2012). Zarubezhnaya praktika nalogooblozheniya $\mathrm{v}$ agrarnom sektore [Foreign taxation practice in the agrarian sector]. Formirovaniye rynochnoy ekonomiki, 27, Part 2, pp. 383-392.

13. Moldavan, L. (2016). Rol kooperatyviv u zabezpechenni konkurentospromozhnosti maloho i serednoho ahrobiznesu: teoretychni i praktychni aspekty [The role of cooperatives in ensuring the competitiveness of small and medium-sized agribusiness: theoretical and practical aspects]. Teoretychni ta prykladni pytannya ekonomiky, 1 (32), pp. 23-31. Retrieved from: http:// tppe.econom.univ.kiev.ua/data/2016_32/zb32_03.pdf.

14. Podatkovyy Kodeks Ukrayiny. Vidomosti Verkhovnoyi Rady Ukrayiny (VVR) 2011 No 13-14, No 15-16, No 17, st. 112 [Tax Code of Ukraine. Official Bulletin of the Verkhovna Rada of Ukraine (OBVRU) 2011 No 13-14, No 15-16, No 17, p. 112].

15. Polyvka, N. (2018). Agroholdingi skoncentrirovali tret' zemel' sel'hozpredpriyatij [Agroholdings concentrated a third of the land of agricultural enterprises]. Ekonomicheskaya pravda. Retrieved form: https://www.epravda.com.ua/rus/news/2018/06/15/637812/] [Accessed 14.04.2019].

16. Pylypchuk, V., Ivasko, I. (2013). Stanovlenie i primenenie pribyl'nogo nalogooblozheniya $\mathrm{v}$ otrasli sel'skogo hozyajstva $v$ stranah ES [Formation and application of profitable taxation in the agricultural sector in the EU countries]. Innovatsiyna Ekonomika 5 (43), pp. 237 -242 .

17. Rasporyazhenie Kabineta Ministrov Ukrainy "Ob odobrenii Koncepcii Gosudarstvennoj celevoj programmy razvitiya agrarnogo sektora ekonomiki na period do 2021 goda" ot 30.12.2015 No 1437-r [Resolution of the Cabinet of Ministers of Ukraine on 20 December 2019 No 1437-r].

18. Shubravskaya, E., Moldavan, L., Paskhaver, B. (2012). Innovacionnye formy organizacii proizvodstva i upravleniya v agropomyshlennom komplekse: mirovoj opyt i puti adaptacii ego k usloviyam Ukrainy NAN Ukrai- 
ny, Institut ekonomiki i prognozirovaniya [Innovative forms of organization of production and management in the agro-industrial complex: world experience and ways of adapting it to the conditions of Ukraine NAS of Ukraine, Institute for Economics and Forecasting]. Natsional'naya akademiya nauk Ukrainy, Kyiv.

19. Tulush, L., Hryshchenko, O. (2018). Transformatsiia vysokotovarnykh hospodarstv naselennia $\mathrm{v}$ subiekty pidpryiemnytstva: podatkovo-biudzhetni aspekty [Transformation of high-value households to entrepreneurs: tax-budget aspects]. Ekonomika APK, 1, p. 40.

20. Ustawa o podatku rolnym $\mathrm{z}$ dnia 15 listopada $1984 \mathrm{r}$. Dz.U. 1985 nr 52, poz. 268 [Agricultural Tax Act of
15 November 1984. Journal of Laws 1985 No 52, item 268].

21. Wasilewski, M., Ganc, M. (2012). Funkcjonowanie systemu podatkowego $\mathrm{w}$ rolnictwie oraz propozycje zmian w opinii rolników indywidualnych [Functioning of the farm taxation system; individual farmers' feedback on changes proposed]. Finanse, Rynki Finansowe, Ubezpieczenia, 50, pp. 725-733.

22. Zakon Ukrainy "O fermerskom hozyajstve" ot 19.06.2003 No 973-IV. Ofitsiynyy Visnyk Ukrayiny 2003, No 29 (01.08.2003), st. 1438 [Farm Act of 19 June 2003. Official Bulletin of Ukraine 2003, No 29 (01.08.2003), p. 1438]. 